IRSTI 06.51 .87

UDC 336.7

https://doi.org/10.46914/1562-2959-2021-1-3-216-222

\author{
Y.S. PATASHKOVA, $* 1$ \\ $\mathrm{PhD}$ student, senior lecturer. \\ *e-mail: e.patashkova@turan-edu.kz \\ ${ }^{1}$ Turan University, Kazakhstan, Almaty
}

\title{
INSIGHTS INTO FINTECH DEVELOPMENT AND TENDENCIES
}

\begin{abstract}
This study examines directions and tendencies of financial technology in all countries. The purpose of the research is to identify and characterize financial technologies, to show the features of their development in modern conditions and revise the foreign experience of regtech, insurtech and blockchain in practical use. Financial future is forming nowadays based not only on facial recognition and blockchain, but also takes into account facial recognition as well as cloud hosting and artificial intelligence. The global financial crisis of 2008 was a turning point that separated the previous phases of the development of financial technologies (Fintech) and regulatory technologies (RegTech) from the current paradigm. Today Fintech has reached onrush condition in its extensive use, characterized by a vigorous startups' uptick and rapid appearance of the new members of financial markets like e-commerce and IT firms that have split the market of financial services. Absolutely new period proposes a conceptual solution to financial problem for regulators and emphasizes the importance of Regtech development along with Fintech propagation. Specifically, regulators should create rather safe new regulatory authority that strengthens market confidence and innovation. It also should be fueled by regulatory sandboxes regular usage. The rapid development of such financial technology as blockchain has the potential to transform the financial market during the pandemic period. Currently, e-wallet payment method is widely used in many countries, which gradually replaced cash as a payment method. Fintech companies today only serve e-wallets. Thus, the use of blockchain is forcing financial regulators to revise existing rules and assess their relevance on a global scale. The paper provides novel insights into development processes of these complex phenomena.
\end{abstract}

Key words: insurtech, financial technologies, digitalization, RegTech, fintech, bitcoin, blockchain.

\section{Introduction}

Financial technologies refer to the innovative use of modern technologies in order to improve the products provision and services delivery in banking, investment, insurance and other areas of financial sphere. These technologies are also found in any company using software, mobile devices, the Internet or the data cloud to create and provide financial services. Nowadays financial technology companies provide alternative financing and compete with banks in most areas of finance, offering their customers innovative financial products and solutions. Fintech is accurately traced to payments in digital form, no matter is it concerned e-commerce (online shopping operations prevalently) or mobile products and services POS-equipped (offline digital payments). Alternative financing as well could be noticed in other market fractions. These type of business provides crowdfunding in different forms for innovative projects and small businesses. Its main option is alternative lending like crowdlending commercially or P2P marketplace lending. Worthy of mention is personal finance, including the automatic distribution of private assets in the form of RoboAdvisors, as well as digital translations [1]. Financial technology outperforms traditional solutions. All banking operations can already be carried out online. In the coming years, banks will increase the share of digital services and there will be almost no traditional financial solutions. For example, crowdsourcing is a kind of innovation in financial technologies. Mobile payments and other services allow customers to access a wider range of financial services. Now it is becoming much cheaper not only to get financing for starting a business, but also for expanding it. Innovative financial technologies are changing the way financial services are provided. Many technologies and business prototypes are the reason for improvement. 


\section{Materials and methods}

The work uses the general methods of scientific knowledge: observation, comparison and analysis. The systemic method is the main way to summarize the information received in this study. The research results provide a theoretical basis for fintech research.

In recent years, startups and entrepreneurs from the innovative financial technology industry have attracted nearly $\$ 1$ billion in investments, according to Innovate Finance data. Innovate Finance notes that the UK took second place in terms of Fintech transactions in 2020. The United States is the leader; China is on the third position. Globally in the history of the Fintech industry, the UK accounted for 12.5 billion investments in 860 deals.

According to MasterCard and Facebook inquiries, fintech arises the interest of people. For instance, more than $90 \%$ of people aged 18-25 in the United States begin to refuse from the bank traditional services and try to shift their financial needs to authentic financial services and technologies. Approximately $70 \%$ of survey informants suppose that traditional banks are absolutely inefficient concerning people's needs. Moreover, the existing financial system can't compare next normal. Half of the respondents are a few steps away from the traditional banking services refusal in the new fintech system favor [2].

Fintech projects could pose a threat to banks, gradually taking away their market share of the so-called risk-free transaction income. For example, a service of cheap money transfers in instant messengers could claim a share of the $1 \%$ commission that a bank charges for transfers between its customers.

\section{Main provisions}

To identify and characterize financial technologies, to show the features of their development in modern conditions and revise the foreign experience of regtech, insurtech and blockchain in practical use the main indicators are defined:

1. The essence and different types of innovative financial technologies

2. Areas of financial technologies application and their advantages

3. The experience of countries in the field of innovative financial technologies.

4. Directions of blockchain technology application.

5. Global private investment in insurtech

\section{Results}

In Figure 1 ( 218 p.), we have presented just a few of the areas outside of finance where startups operate using practical blockchain-based solutions. At the 2018 World Economic Forum, it was announced that governments intend to develop a blockchain-based global identity program for individuals, including travelers, that will someday allow passports to be abandoned. As part of this initiative, Brazil and Canada are also discussing national blockchain-based identity identification programs [3].

Cryptocurrencies are known to be virtual currencies that use blockchain technology to track transactions across a network of computers. They can be used as an alternative currency to buy goods and services, but many people buy them as investments in the hopes that their value will rise because others will want them in the future. In 2020, Bitcoin held $66 \%$ of the total cryptocurrency market.

Bitcoins are traded on several independent exchanges around the world and prices may vary. The Bitcoin Price Index shows the average price on the world's leading exchanges. Virtual currency has a fickle trading history when it was incepted for the first time in 2009. It was in 2013 when the price increased firstly. In November 2013 one bitcoin traded at around USD 1,124. But in 2017 bitcoin experienced explosive growth and reached the maximum pricing being traded at roughly 20,000 USD per one bitcoin at the end of the year. However, in the following months, prices soon began to fall. In the third quarter of 2020, there were about 18.5 million bitcoins inhands in the world, and the capitalization of bitcoins markets was as much as about 210 billion USD [4]. 


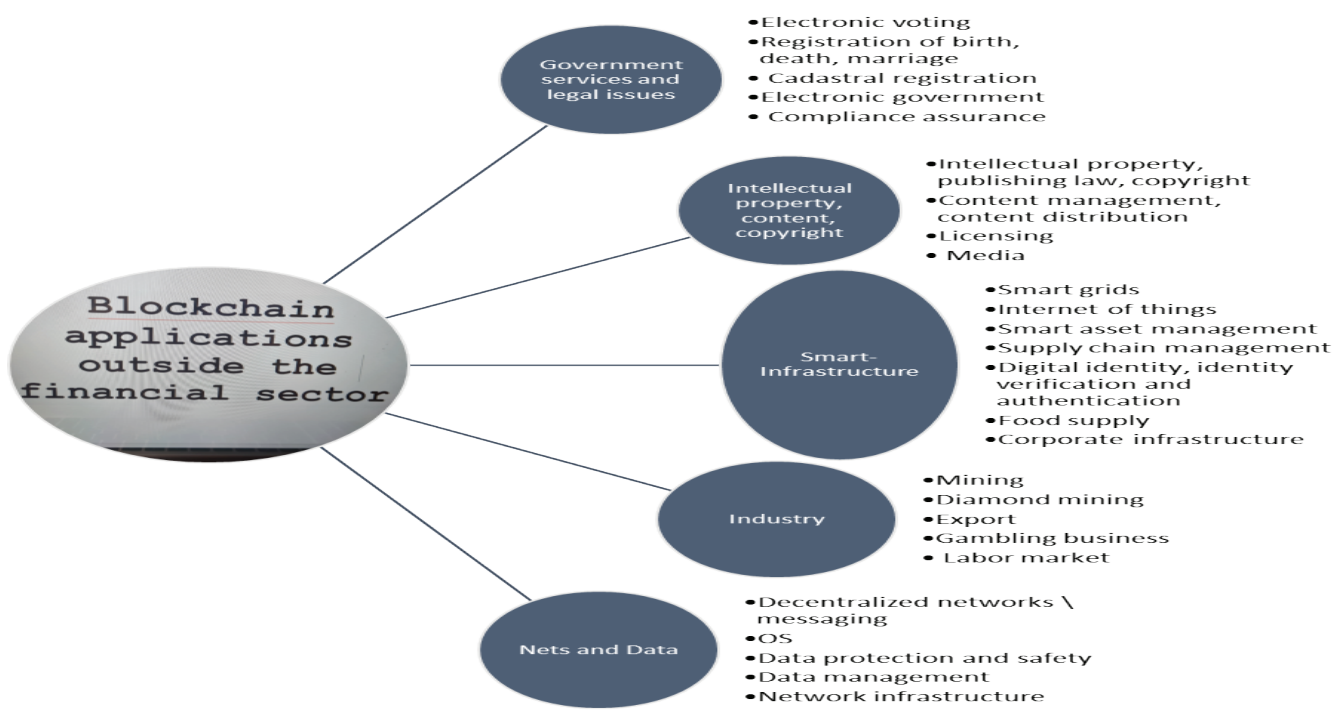

Figure 1 - Examples of blockchain technology application

Note - Developed by the authors.

Over the past eight years, the price of bitcoin has increased by 1400 times.

The number of bitcoin ATMs around the world has grown in a gradual mode since 2015, hitting an all-time high in early 2021. On February 1, 2021, it was counted almost 14,000 bitcoin ATMs worldwide. There are two main bitcoin ATMs in the world: basic, allowing users to buy only bitcoins, and complex, allowing users to sell as well as to buy virtual money. As for complex ATMs, the members of a specific ATM manufacturer only can use this ATM. On August 2020, the main Bitcoin ATM manufacturers were General Bytes and Genesis Coin with 30.4\% and 34.7\% market share, respectively. The largest number of Bitcoin ATMs were registered in the United States in September 2020. In total, about $83 \%$ of the world's ATMs were located in North America [5].

The transaction amount is expected to show an annual growth rate (CAGR 2021-2025) of 3.3\%, leading to a projected total of USD 1201.1 million by 2025. The average funding for one campaign in the crowdfunding segment is 5,726 USD in 2021. In terms of a global comparison, it is shown that the highest transaction value is achieved in the United States (504 million USD in 2021).

In the crowdfunding segment, 174.7 thousand financing campaigns are expected by 2025 (Figure 2).

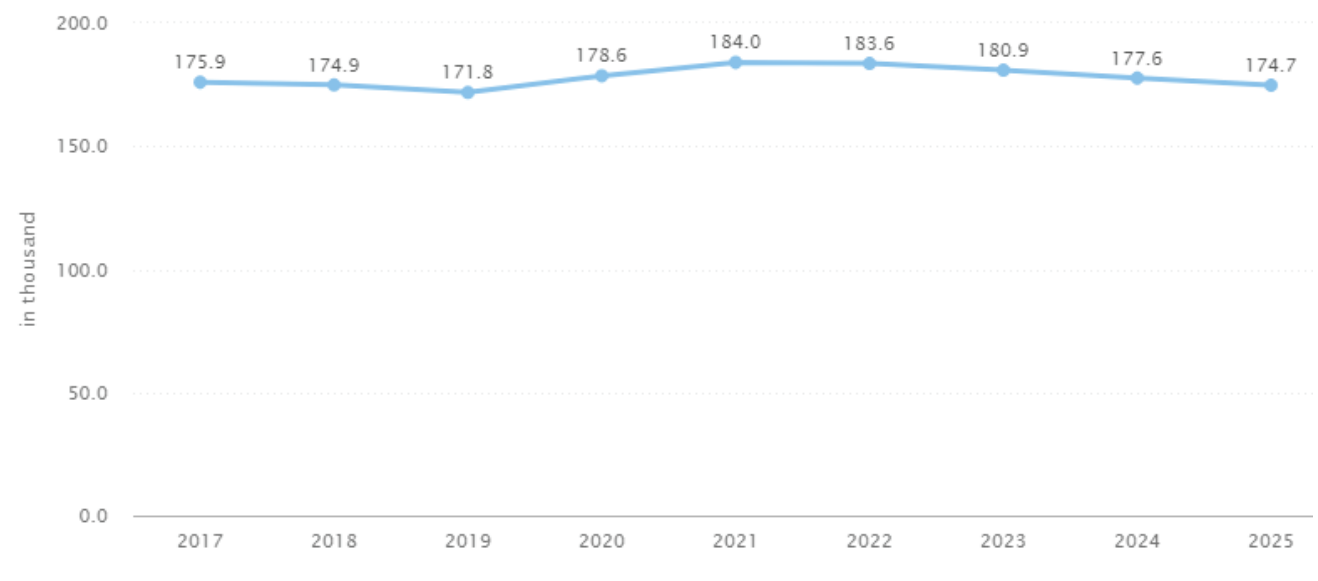

Figure 2 - Number of campaigns in thousands

Note - Developed by the authors based on https:/www.statista.com/outlook/335/100/crowdfunding/ worldwide\#market-users [6]. 
Figure 2 displays the number of funding campaigns successfully completed (in the last 12 months) in the selected market and region.

\section{Discussion}

The experience of countries in the field of innovative financial technologies. Europe. Cryptocurrency and blockchain startups are trying to enter the UK market faster, and then begin further expansion to Europe:

- Coinsilium, an investment company in London, launched trading in its shares on the Derivatives Exchange;

- The American blockchain company itBit, which owns the Bitcoin exchange of the same name, has hired Jason Nabi, the head of the after-sales department at Societe Generale, in order to head his new office in London, through which the company plans to begin expansion in Europe, the Middle East and Africa

- in mid-January 2020, heading the blockchain startup Digital Asset Holding, announced the opening of a company office in London;

- At the end of November 2019, BitFury opened its office in the largest European technological and financial technology accelerator Level 39 in order to facilitate the access of European companies to their research and developments in blockchain technology.

Great Britain is a serious competitor for Silicon Valley on the issue of leadership for its role as the leading global Fintech center [7].

U.A.E. Speaking at the recent CIOMajlis (Chief Information Officer) meeting regarding Blockchain technology, CIOMajlis Chairman Ahmad Al Mulla stated that Dubai is a leader in the use of the latest technologies and has set itself the goal of being the first in the world to fully switch to all operations using blockchain technology by 2021 . Government initiatives in this direction provide tremendous opportunities for private business in the UAE

According to information provided by Trade Arabia, Sheikh Hamdan bin Mohammed bin Rashid Al Maktoum, Crown Prince of Dubai and Chairman of the Dubai Executive Council has announced the launch of the Dubai Blockchain project. Thus, he seeks to launch a study of technologies that could further benefit the residents of the UAE. Den Frankel, a Dubai-based Blockchain City Consultant who has been named the Official Blockchain Technology Advisor of the City of Dubai, said that decentralized accounting technology could cut transaction costs by 15-20 billion USD per year by 2022 by eliminating manual processing costs, errors in processing and cyclical execution of the same tasks.

Wanting to back up words with deeds, the country began to work decisively. Already in June, the government of Dubai and Objectech (Blockchain startup) signed an agreement about digital passports that should be used in Dubai International Airport. Thus, they want to abandon passport control by creating the world's first "border without borders". This is not the only example: the banking giant Emirates NBD also intends to implement a distributed ledger in order to prevent falsification. The Dubai government is giving the green light to blockchain systems across all industries, which could well be the first blockchain nation [8].

Indonesia. In 2015, President Joko Widodo noted that by 2020, Indonesia should become the largest economic power in Southeast Asia. At that time, he led the Indonesian delegation to Silicon Valley in the United States of America. Together with the Minister of Communications and Information and the office, Tokopedia and four other technology startups in Indonesia participated. Specialists learn about the experience of the United States of America and learn from global global technology companies in Silicon Valley. Two years later, three out of five Indonesian startups were transformed into unicorn, a company whose value exceeded 1 billion USD (14 trillion rupees). Tokopedia is the first company in Southeast Asia to receive \$ 100 million from Sequoia Capital and SoftBank. Sequoia Capital is the venture capitalist behind the successes of Google and Apple, when the business was still a garage-built business. SoftBank is the financier of Alibaba's success. This flow of global investor funds to Indonesia shows global confidence that a country is not just a market, but a country that can become a global technology player. Previously, they have always been focused on the allocation of capital to the United States, China and India. In the previous decade, Internet users in Indonesia had 
to agree to use only foreign-made products. The policy is such that with the huge investment made by local entrepreneurs in recent years, Indonesia has been able to produce world-class high-quality Internet products such as Tokopedia, Go-jek and Traveloka. The domestic technological industry has become excellent. This stimulates the growth of human resources that are needed in the industrial revolution 4.0 [9].

Financial technologies help buy and sell transactions, and therefore payment systems become more performant and cost-effective. Take a look at the legal framework of the Indonesian financial technologies operation in the payment system, such as:

1. Bank of Indonesia regulations no. 18/40 / PBI / 2016 on the implementation of payment processing.

2. Bank of Indonesia Circular No. 18/22 / DKSP regarding the introduction of digital financial services.

3. Bank of Indonesia Regulations no. 18/17 / PBI / 2016 on electronic money [10].

For Indonesian consumers, the benefits of financial technology consist of receiving improved service, more choices and options, and a reduced price. For sellers of goods or services, financial technology provides a simplified transaction chain, reduced operational and capital costs, stop the flow of information.

For Indonesia, financial technology provides advantages: encouraging the transfer of economic policies, increasing the speed of money, thus increasing the economy of society; in Indonesia, support for financial technology consists of a developed National strategy of financial inclusion [11].

Financial technologies have changed the payment system in society and helped start-up companies reduce capital costs, high operating costs at the beginning.

Kazakhstan. Chocofamily Holding is one of the largest e-commerce companies in Kazakhstan. The holding includes seven companies: Chocolife.me collective purchase service, BeSmart collective purchase service, Chocotravel.com real-time train and airline ticket purchase service, Chocomart. kz, Lensmark.kz online stores, food ordering and delivery service Chocofood.kz, iDoctor.kz doctor search service, Rakhmet application.

Silkway Ventures Group. The company is one of the largest Internet projects in Kazakhstan. At present, Fintech holding includes six companies: the marketplace of the best offers of banks, MFIs and online lenders of Kazakhstan - Prodengi.kz, the online loan service Credit24, the digital agency Klikobilie, a retail lending company in the form of Micro MFIs, peer-to-peer online lending service in Vietnam MoneyBank, market place for microloans based on Lendex blockchain technology.

Thanks to the agreement, Kazakhstan became the first country from Central Asia to join the Mintos loan market. This will allow European citizens to invest directly in online loans in tenge using the "mutual lending" tool (peer-2-peer).

In March 2018, the National Bank of the Republic of Kazakhstan launched the Invest Online system, with its help you can invest funds in the notes of this bank in real time and work with securities of large Kazakh companies. Invest Online is based on such innovative solutions as blockchain technology, as well as electronic money issued by the National Bank of the Republic of Kazakhstan for settlements on securities transactions. The process of calculating income can be monitored by going to your personal account in the system.

In July 2018, the AIFC officially opened. The AIFC report which was published in 2020, highlighted Kazakhstan as the leader of Internet providing among all the CIS countries. According to its data, more than $75 \%$ of the Kazakhstani people go online at least once a week, as well as approximately $35 \%$ of residents constantly use mobile Internet.

However, along with the positive aspects, there are still a large number of certain factors that inhibit the development of fintech in Kazakhstan. Despite the fact that the state regulates the financial sector in the country, such a system lags significantly behind modern trends. Digital identification does not work 100 percent in Kazakh banks, therefore, some banking services cannot be provided remotely. The reason for this is the official status of such a system, which is not enshrined in the country's legislation. It should be emphasized that remote identification is a fairly popular trend in the global banking sector, especially during a pandemic. Taking this into account, we can say that in Kazakhstan 
there is not a very favorable atmosphere for the development of fintech startups, which are needed and needed today.

\section{Conclusions}

The present paper has concentrated on the analysis of financial technologies and its collaborations. Having considered the available data, one can conclude that today's financial market is, in the first place, a market of fintech, start-ups, regtech and insurtech. The research interest in blockchain and cryptocurrency is constantly growing.

Despite all the difficulties of 2020, the coronavirus crisis also caused a revolutionary development in some industries. In particular, there has been an e-commerce boom all over the world and the active development of financial technologies.

2020 has changed the consumer culture - more and more people are choosing services and learning online. The pandemic has accelerated the transition to digital.

Serious revolutionary changes under the influence of the fintech segment begin change the nature of lending and payment practices, with the next wave such changes are already looming in the asset management and insurance sectors services. Our research has shown that this opinion is confirmed by representatives of these sectors. Almost half of insurers and asset managers and private capital consider their areas of activity to be those segments that in most affected by revolutionary changes.

Thus, financial technology has expanded to cover the full range of financial services. Reciprocally fintech is covered into such key spheres: user interfaces, investment, internal operations, finance, risk management, infrastructure and payments, monetization and data security. Financial technology involves integrating technology into financial transactions such as algorithmic trading and crowdfunding. For another thing, fintech is rather important for internal organizations and operations, as suggested by increased number of costs that worldwide financial institutions invest in expanding their IT capacity.

\section{REFERENCES}

1 Altamura C., Daunton M. Finance, financiers and financial centers: A special issue in honor of Youssef Cassis Introduction. - Financial History Review, 2020. 27(3). - P. 283-302. URL: https://doi.org/10.1017/ S0968565020000153

2 Grennan J., Michaely R. Fintechs and the Market for Financial Analysis. - Journal of Financial and Quantitative Analysis, 1-31. 2020. URL: https://doi.org/10.1017/S0022109020000721

3 Popovic D., Avis C., Byrne M., Cheung C., Donovan M., Flynn Y., Shah J. Understanding blockchain for insurance use cases. - British Actuarial Journal, 2020. 25. E13. URL: https://doi.org/10.1017/ S1357321720000148

4 Ranchordas S. Introduction to the Symposium on Blockchain Regulation and Governance. - European Journal of Risk Regulation, 2019. 10(2). - P. 243-244. URL: https://doi.org/10.1016/j.ijhm.2017.01.090

5 Rust K. Block-chain Reaction: Why Development of Blockchain is at the Heart of the Legal Technology of Tomorrow: Overall Winner, Justis International Writing Competition 2019 by Kimberley Rust of the University of Sheffield. - Legal Information Management, 2019. 19(1). P. 58-60. URL: https://doi.org/1017/ S1472669619000124

6 Statista. The company behind www.statista.com one of the world's leading statistics portals. URL: https://www.statista.com/statistics/638850/consumer-usage-of-financial-services-usa/

7 Ringe W., Ruof C. Regulating Fintech in the EU: The Case for a Guided Sandbox. - European Journal of Risk Regulation, 2020. 11(3). P. 604-629. URL: https://doi.org/10.1017/err.2020.8

8 Bloomberg official website. URL: https://www.bloomberg.com

9 Indonesia. Internet media, information and research company in the field of economics and business. URL: https://katadata.co.id

10 Kharisma Dona. Urgency of financial technology (Fintech) laws in Indonesia. -International Journal of Law and Management. ahead-of-print, 2020. URL: https://doi.org/10.1108/IJLMA-08-2020-0233

11 Bank of Indonesia official website. URL: https://www.bi.go.id 
Е.С. ПАТАШКОВА,*1

докторант, ст. преподаватель.

*e-mail: e.patashkova@turan-edu.kz

${ }^{1}$ Университет «Туран», Казахстан, г. Алматы

\title{
К ВОПРОСУ О НАПРАВЛЕНИЯХ И ТЕНДЕНЦИЯХ РАЗВИТИЯ FINTЕСН
}

\begin{abstract}
Аннотация
В этом исследовании рассматриваются направления и тенденции финансовых технологий во всех странах. Цель исследования - выявить и охарактеризовать финансовые технологии, показать особенности их развития в современных условиях и пересмотреть зарубежный опыт regtech, insurtech и blockchain в практическом использовании. От блокчейна до облачного хостинга, распознавания лиц и искусственного интеллекта будущее финансов формируется прямо сейчас. Мировой финансовый кризис 2008 г. стал поворотным моментом, отделившим предыдущие фазы развития финансовых технологий (Fintech) и технологий регулирования (RegTech) от нынешней парадигмы. Сегодня финтех вступил в фазу быстрого роста, отмеченного быстрым увеличением числа стартапов и других новых участников, таких как фирмы в области ИТ и электронной коммерции, которые фрагментировали рынок финансовых услуг. Новая эра ставит новые задачи перед регулирующими органами и подчеркивает, почему эволюция Fintech требует параллельного развития RegTech. В частности, регулирующие органы должны разработать прочную новую структуру, которая будет стимулировать инновации и доверие рынка, опираясь на использование регуляторных «песочниц». Некоторые разработки RegTech сегодня указывают путь к еще одному сдвигу парадигмы, который будет отмечен переосмыслением природы финансового регулирования. Быстрое развитие финансовых технологий, блокчейна может изменить финансовый рынок в период пандемии. В настоящее время во многих странах широко используется способ оплаты через электронный кошелек, который постепенно вытеснил наличные в качестве способа оплаты. Сегодня финтех-компании обслуживают только электронные кошельки. Таким образом, использование блокчейна вынуждает финансовые регуляторы пересматривать существующие правила и оценивать их актуальность в глобальном масштабе. В статье представлены новые взгляды на процессы развития этих сложных явлений.
\end{abstract}

Ключевые слова: insurtech, финансовые технологии, цифровизация, RegTech, финтех, биткойн, блокчейн.

Е.С. ПАТАШКОВА, докторант, аға оқытушы.

*e-mail: e.patashkova@turan-edu.kz

${ }^{1}$ «Тұран» университеті, Қазақстан, Алматы қ.

\section{FINTЕСН ДАМУЫНЫН БАҒЫТТАРЫ МЕН ҮРДІСТЕРІ ТУРАЛЫ МӘСЕЛЕЛЕР}

\begin{abstract}
Андатпа
Бұл зерттеуде барлық елдердегі қаржылық технологиялардың бағыттары мен тенденциялары қарастырылады. Зерттеудің мақсаты - қаржылық технологияларды анықтау және сипаттау, олардың қазіргі жағдайда даму ерекшеліктерін көрсету және regtech, insurtech және blockchain тәжірибесін іс жүзінде қолданудың шетелдік тәжірибесін қайта қарау. Блокчейннен бастап бұлтты хостингке, тұлғаны тануға және жасанды интеллектке дейін қаржы болашағы дәл қазір қалыптасуда. 2008 ж. дүниежүзілік қаржылық дағдарыс қаржылық технологияның (Fintech) және реттеуші технологияның (RegTech) алдыңғы кезеңдерін қазіргі парадигмадан бөліп қараған бетбұрысты кезең болды. Қаржы қызметтері нарығын бөлшектеген IT және электронды коммерциялық фирмалар сияқты стартаптардың және басқа да жаңа қатысушылардың жылдам өсуімен ерекшеленетін Fintech бүгінде қарқынды өсу кезеңіне аяқ басты. Бұл жаңа дәуір реттеушілер үшін жаңа қиындықтар туғызады және неге Fintech эволюциясы RegTech-тің қатар дамуын қажет етеді. Атап айтқанда, реттеуші органдар регуляторлық құм жәшіктерін пайдалану арқылы қозғалатын инновациялар мен нарықтық сенімділікті дамытатын берік жаңа құрылымды әзірлеуі керек. RegTech-тің бірнеше әзірлемелері қаржылық реттеудің табиғатын қайта қарастырумен сипатталатын тағы бір парадигмалық ілгерілеуге жол көрсетеді. Қаржы технологияларының қарқынды дамуы, блокчейн пандемия кезеңінде қаржы нарығын өзгерте алады. Қазіргі уақытта көптеген елдерде электрондық әмиян төлем әдісі кеңінен қолданылады, бұл төлем әдісі ретінде қолма-қол ақшаны біртіндеп алмастырды. Бүгінде финтех-компаниялар тек электрондық әмияндарға қызмет етеді. Осылайша, блокчейнді қолдану қаржылық реттеушілерді қолданыстағы ережелерді қайта қарауға және олардың өзектілігін жаһандық масштабта бағалауға мәжбүр етеді. Мақалада осы күрделі құбылыстардың даму процестеріне жаңа көзқарастар берілген.
\end{abstract}

Тірек сөздер: insurtech, қаржылық технология, цифрландыру, RegTech, финтех, биткойн, блокчейн. 